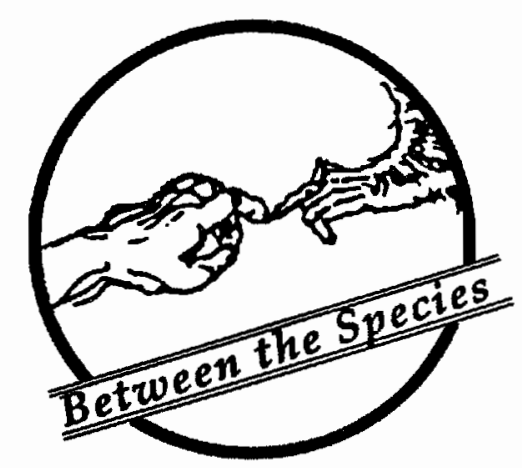

\title{
CHRIST, THE ANIMIST
}

\section{George Abbe}

\section{The World Is Too Much With Us}

The world is too much with us; late and soon,

Getting and spending, we lay waste our powers:

Little we see in Nature that is ours;

We have given our hearts away, a sordid boon!

The sea that bares her bosom to the moon; The winds that will be howling at all hours, And are up-gathered now like sleeping flowers;

For this, for everything, we are out of tune; It moves us not. - Great God! I'd rather be A pagan suckled in a creed outworn.

So might I, standing on this pleasant lea, Have glimpses that would make me less forlorn;

Have sight of Proteus rising from the sea; Or hear old Triton blow his wreathed horn.

\section{-William Wordeworth}

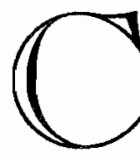

hrist was essentially an animist, though the churches have concealed this from us. All things - the lily, the sparrow, the ox, were equally sacred in his eyes. The ego of man distorted and censored his words when composing the Bible, an instrument to expedite the authority of a human institution, and so demeaned all other life to serve ecclesiastical purposes. If the slaughtered lamb was declared to be as important to God as the herdsman and owner (which I am sure Christ believed), then the priest could not persuade his people that God operated through the superior power and wisdom of one species (the human vessel of divinity), and the structure of law would be threatened.

But law, as we know it, must be superseded by love - for all things, equally - or the planet is doomed. Jesus knew and said this, but his message has been obscured, falsified, and diminished.

Walk in the fields, and if you drop your eyes frequently to the path before you - which you should do - you'll note an insect, red, black, and gray perhaps, struggling up a blade of grass. Be careful

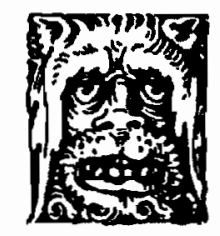


not to step on it (whenever you walk, on pavement or earth, you should keep the life beneath you in mind); but do more than that - bend down and observe the insect. Wish it Godspeed. Examine its coloring and movement; reflect how it has all the basic drives you have - hunger, sex, security, contentment, sleep, curiosity, companionship.

Then as you continue on, passing through a stand of brown weeds, run your fingers over the prickly seed, the dry white floss, murmuring aloud:

"Good rest and satisfaction, old friends who made my summer vivid-hued, vital with movement. Sleep and remember and waken to feel your continuing significance in the world of winter. Be the food for birds. And as you fall and are buried and absorbed in earth, sense the gratitude and praise of Christ, the reward and honor he gives to all things which - unlike man - are true to Nature, are true to the natural imperatives in them; for these demands are beautiful and just; they are the will of God. But man, corrupted and false and arrogant, denied the will of God in him, and so, increasing evil, he must suffer a towering Karmic debt - which draws nearer and nearer, and must be paid - soon - and ever sooner - in earth convulsions, in cataclysms and plagues, in manmade devastations - indescribable reckonings."

If you see a bee in the hay of your barn, there is Christ, sounding and moving in his own secret way. Handle the hay reverently, for the bee may plan to house himself there until the bitter cold; and as Blake said:

$$
\begin{aligned}
& \text { So cherish pity } \\
& \text { lest you drive } \\
& \text { an angel from your door. }
\end{aligned}
$$

Do not use that hay, but place it aside where the bee may nestle and build a refuge with his fellows. For your kindness will revert to you, will flower in the blossoms and songs and honey of all the summers to be.

If you notice the blue of chicory, dust-covered but breathing, beside the road, Christ strives for survival there. Man is sick and vicious, befouled by his own wastes; he is doomed. Nature is innocence, and that is why you should touch the chicory and bless it; for it is what he called "the least of these, my brethren," the most worthy of love and help; inasmuch as we give to them, the meek, the natural, and lowly, we give to Him.

And although the bee must die in the cold, his natural cycle has been aided by your affection; and that he will never forget, not the natural order he springs from, nor the Christ which is Conscious Purpose in Nature, the Divine, Communal Companionship and Creative Exultation that is the sure completion for all things.

When you look on the tree, the plant, the stone, realize that the true equality is there; the genuine Christ and His church will be born from these things. They are the meek and lowly he spoke of - as is the human child. The long-established institutional churches have been the chief agents of our decay because they extirpated animism, the pagan sense of God's imminence, His multiplicity, and all-inclusiveness, His absolute totality and mutuality of holiness - what St. Francis preached and was assailed by the Church for preaching. Undoubtedly, mankind will turn to this redemptive and regenerative view as a world religion - we shall have to turn to it soon - if we are to survive at all.

William Wordsworth knew that our scientificindustrial age would annihilate the intuitive-spiritual in man; he bewailed the rejection of that pagan animism which had created those exalting imaginative concepts of Triton, Ceres, Atlas, Jupiter, Athena. They expressed the reality of fantasy, the vast and fertile divinity of the imagination - for in all that man mystically and intuitively invents, as in all that he perceives through the senses, is the Spirit, the animus, the love and compassion that is too powerful to be contained in one being, but overflows as deity into creature, object, every particle.

Yes, we shall be forced to dedicate ourselves at last to a fresh religion - the Church of the Holy Ecology perhaps - a revolutionary Christian animism - a St. Francis paganism, if you will the immersion in the waters of sacred variety and proliferation which Wordsworth describes in "The World is Too Much With Us" - the extrasensory awareness of the Presence in limitless guises all about, sensitive and responsive to our outcry, our prayer, quickening the myriad forms of Nature from which we have all come - for, life after life, we broaden our experience and identity. 